\title{
The Oakland Project
}

At a time when much is said but little is done about the university's relationship to urban problems, it is useful for those who are looking for ways of relating the university to the city to take a brief look at the Oakland Project of the University of California, which combined policy analysis, service to city officials and community groups, action in implementing proposals, training of graduate students, teaching new undergraduate courses, and scholarly studies of urban politics. The "university" is an abstraction, and as such it exists only for direct educational functions, not for the purpose of doing work within cities. Yet there are faculty members and students who are willing to devote large portions of their time and energy to investigating urban problems and to making small contributions toward resolving them. Our cities, however, do not need an invasion of unskilled students and professors. There is no point in hurtling into the urban crisis unless one has some special talent to contribute. After all, there are many people in city government-and even more on street corners-who are less inept than untrained academics. University people must offer the cities the talent and resources which they need and which they could not get otherwise.

In 1965 a group of graduate students and faculty members 
at the University of California at Berkeley became involved in a program of policy research and action in the neighboring city of Oakland. As members of the Oakland Project, they tried to meet some of the city's most pressing analytical needs and also to make suggestions that could be implemented.

Members of the project made substantial time commitments (usually about two years) to working in a particular Oakland city agency. Normal working time was two days a week, although special crisis situations in the city sometimes necessitated much larger blocks of time. Since project members worked with city officials and remained in the city to help implement the suggestions they made, they avoided the "hit-and-run" stigma that members of city agencies often attach to outsiders. By attempting first to deal with problems as city officials understand them, project members developed the necessary confidence to be asked to undertake studies with broader implications.

The Oakland Project became a point of communication for individuals and groups in the city of Oakland and throughout the University of California. Its focus expanded from a concentration on city budgeting to a wide range of substantive policies and questions of political process; for example, revenue, police, personnel, federal aid, education, libraries, and the institutionalization of policy analysis. The Project provided assistance to governmental (mayor, city manager, chief of police, head of civil service, superintendent of schools) and nongovernmental (community group) actors. In order to transmit the knowledge gained, Oakland Project members taught courses-open to both undergraduate and graduate students-dealing with urban problems and policies. The Project's scholarly objective is to improve policy analysis by providing new ways of understanding decisions and outcomes that affect cities. Its members have based numerous research essays on their experience in the city. It is hoped that the books in this series will be another means of transmitting what they have learned to a wider audience. 